\title{
Critical Thingking and Decision Making Skills Based Learning Methods at The Faculty of Nursing Universitas Padjadjaran
}

\author{
Citra Windani Mambang Sari ${ }^{1}$, Siti Yuyun Rahayu Fitri ${ }^{2}$, Efri Widianti ${ }^{3}$ \\ ${ }^{1,2,3}$ Fakultas Keperawatan, Universitas Padjadjaran \\ Email: ${ }^{1}$ ners_citra@yahoo.com
}

\begin{abstract}
ABSTRAK
Metode pembelajaran yang diberikan sangat berpengaruh dalam kemampuan berpikir kritis dan keterampilan mahasiswa perawat dalam mengambil keputusan. Kemampuan berfikir kritis dan keterampilan mengambil keputusan ini merupakan dua hal yang dapat dijadikan dasar untuk melihat kompetensi lulusan perawat. Tujuan dari penelitian ini adalah mengidentifikasi kemampuan berpikir kritis dan keterampilan mengambil keputusan pada mahasiswa Fakultas Keperawatan. Metode penelitian adalah deskriptif kuantitatif dengan jumlah sampel 151 mahasiswa. Analisis data menggunakan distribusi frekuensi. Hasil penelitian adalah Lebih dari setengah responden $(66,2 \%)$ memiliki kemampuan berpikir kritis diatas rata-rata kelompok $(\mathrm{M}=186,19, \mathrm{SD}=33,92)$. Lebih dari setengah responden memiliki keterampilan mengambil keputusan di atas rata-rata kelompok $(\mathrm{M}=94.92, \mathrm{SD}=9.52)$. Sebagian kecil responden dengan IPK 3.01-3.25 memiliki kemampuan berpikir kritis dan keterampilan mengambil keputusan diatas rata-rata kelompok. Sebagian kecil responden latar belakang jurusan IPA memiliki kemampuan berpikir kritis dan keterampilan mengambil keputusan diatas rata-rata kelompok. Kemampuan berpikir kritis dan keterampilan mengambil keputusan sebaiknya dimasukkan ke dalam kurikulum akademik sehingga terwujud perawat profesional.
\end{abstract}

Kata kunci : berpikir kritis, mengambil keputusan, mahasiswa perawat

\section{ABSTRACT}

Methods of learning in nursing students affect the ability of critical thinking skills and student nurses in making decisions. The ability of critical thinking and decision making skills are the two things that can be used as a basis to see competence of nurse graduates. The aim of this study is to identify the critical thinking skills and decision making skills in student Faculty of Nursing, Universitas Padjadjaran. The research method is quantitative descriptive with a sample of 151 students. Data analysis using frequency distribution. Results of the study were more than half of the respondents $(66.2 \%)$ have the ability to think critically above the group average $(M=186.19, S D=33.92)$. More than half of respondents have a decision-making skills in the above average group $(M=94.92, S D=$ 9.52). A small portion of respondents with a GPA of 3.01 to 3.25 to have critical thinking skills and decision making skills above the group average. A small portion of respondent background science majors have the critical thinking skills and decision making skills above the group average. The ability of critical thinking and decision making skills should be incorporated into the academic curriculum as soft skills to realize a professional nurse.

Keywords : critical thingking, decision making, nursing student, skill.

\section{INTRODUCTION}

Technological development and condition of health of the Republic of Indonesia demanding nurses have competence in the field. It also requires the Faculty of
Nursing to produce quality graduates. Qualified graduates may impact on the learning process received during the lecture.

One of the things that can affect learning method that is used by faculty in giving 
lectures. This is consistent with the concept of learning that has been set in the Government Regulation No.19 / 2005 pasal 19 that the learning process in the educational unit organized in an interactive, inspiring, fun, challenging, motivating learners to actively participate and provide enough space for innovation, creativity and independence in accordance with their talents, interests and physical and psychological development of learners.

Along with the research results, methods of competency-based curriculum has been used in the methods of teaching in the Faculty of Nursing, University of Padjadjaran with small group discussion method (SGD). This method consists of 7 process that aims to make nursing students more active and creative. In addition to these methods, Faculty of Nursing, University Padjadaran also still using methods Teacher Learning Center on a non regular student. but it also performed other teaching methods are peer teaching.

Learning Method given very influential in critical thinking skills and the skills of nursing students in making decisions. The ability of critical thinking and decision making skills are the two things that can be the basis for the competence of graduate nurses.

The aim of this study is: 1. Identify the critical thinking skills to students of the Faculty of Nursing 2. Identify the skills to make decisions on the students of the Faculty of Nursing

\section{METHOD}

This type of research is descriptive quantitative research methods. The group is a group of students of the Faculty of Nursing, University of Padjadjaran 7th semester ever using the Small Group Discussion and methods of peer teaching as a learning method.

The population in this study is the seventh semester students as many as 151 people. The sample in this research were 151 people who were taken using concecutive sampling technique. The study was conducted at the Faculty of Nursing, University of Padjadjaran in Jatinangor year of the study during the first semester of the year 2014/2015.

The research instrument is divided into three. First, demographic questionnaire respondents consisting of gender, religion, ethnicity, background of high school, GPA and the use of the Internet as a learning. The second instrument is the ability to think critically. Questionnaires critical thinking skills wearing of California Critical Thinking Disposition Inventory (CCTDI) of Facione \& Facione (1992). This questionnaire consists of 75 statements with Likert-scale rating are Strongly Agree, agree, undecided, disagree and strongly disagree. The third was instrument of the decision-making skills. The questionnaire was a questionnaire study of Bowers (2004), which consists of 40 statements with a choice of answers always, often, sometimes, rarely and never. The second and third questionnaire has been translated into Indonesian (back-translation).

Data were collected on the campus of the Faculty of Nursing, University of Padjadjaran. Data collection consisted of the preparation phase and the implementation phase. The preparation phase conducted by obtaining the permission of the S1 Nursing Program, prepared materials and questionnaire packet including informed consent. Data collection phase begins with collecting samples that meet the criteria to participate in this study. The ability of critical thinking and decision making skills are taken during the 7 th semester students already undergoing Comprehensive Clinical Skill Analysis (CCSA II).

Univariate analysis or descriptive statistics used were percentage, frequency, mean, median, mode, standard deviation, minimum and maximum values as well as the confident interval (CI 95\%) according to the scale of variable data. Data on age, sex, use of 
learning methods using frequency distribution and percentage. Data critical thinking skills and decision making skills are presented in the form of frequency distribution and the mean percentage of the categories below and above the mean (the ability to think critically $\mathrm{M}=186.19$; skills to make decisions $\mathrm{M}=$ 94.42). To see a picture of the relationship between the GPA and the background of majors using crosstab analysis.

\section{RESULT}

Table 1. Characteristics of respondents

\begin{tabular}{|c|c|c|}
\hline Variable & $\mathbf{N}$ & $\begin{array}{c}\text { Persentage } \\
(\%)\end{array}$ \\
\hline \multicolumn{3}{|l|}{ Gender } \\
\hline - Female & 142 & 94 \\
\hline - Male & 9 & 6 \\
\hline \multicolumn{3}{|l|}{ Ethnic } \\
\hline - Sunda & 74 & 49 \\
\hline - Javan & 30 & 19.9 \\
\hline - Minang & 16 & 10.6 \\
\hline - Batak & 17 & 11.3 \\
\hline - Other & 14 & 9.3 \\
\hline \multicolumn{3}{|c|}{ Background Senior High School } \\
\hline - Science & 143 & 94.7 \\
\hline - Social & 2 & 1.3 \\
\hline - Technic & 2 & 1.3 \\
\hline - Other & 4 & 2.6 \\
\hline \multicolumn{3}{|l|}{ Domicile } \\
\hline - Live with parents & 63 & 41.7 \\
\hline $\begin{array}{l}\text { - with brothers or } \\
\text { sister }\end{array}$ & 4 & 2.6 \\
\hline - rent room & 81 & 53.6 \\
\hline - Other & 3 & 2 \\
\hline \multicolumn{3}{|l|}{ Have a PC / laptop } \\
\hline - Yes & 148 & 98 \\
\hline - No & 2 & 2 \\
\hline \multicolumn{3}{|c|}{ The desire entered the Faculty of Nursing } \\
\hline - by self & 85 & 56.3 \\
\hline - by parents & 44 & 29.1 \\
\hline - by friend & 1 & 0.7 \\
\hline - others & 21 & 13.9 \\
\hline \multicolumn{3}{|c|}{ Finding the source via the Internet } \\
\hline - Yes & 150 & 99.3 \\
\hline - No & 1 & 1 \\
\hline \multicolumn{3}{|c|}{ Websites that are frequently open } \\
\hline - Google Scholar & 133 & 88.1 \\
\hline - Google & 17 & 11.3 \\
\hline - Other & 1 & 0.7 \\
\hline \multicolumn{3}{|c|}{ Borrow books at the library } \\
\hline - Yes & 145 & 96 \\
\hline - Never & 6 & 4 \\
\hline
\end{tabular}

\begin{tabular}{lcc}
\hline \multicolumn{3}{l}{ Borrowing books in the Library (in weeks) } \\
- $\quad$ Never & 11 & 7.3 \\
- 1 times & 96 & 63.6 \\
- 2 times & 37 & 24.5 \\
- 3 times & 5 & 3.3 \\
- 4 times & 2 & 1.3 \\
\hline GPA & & \\
- $2.5-2.75$ & 3 & 2 \\
- $2.76-3.00$ & 21 & 13.9 \\
- $3.01-3.25$ & 86 & 57 \\
- $3.25-3.5$ & 39 & 25.8 \\
Wearing glasses & 2 & 1.3 \\
\hline - Yes & & \\
- No & 66 & 43.7 \\
\hline
\end{tabular}

Table 1 illustrates the characteristics of respondents. Almost all (94\%) of the respondents were women. Most of the Sundanese (49\%). Almost entirely of respondents are against a background of high school students majoring in science (94.7\%). More than half of respondents (53.6\%) lived with kos way around campus. More than half of respondents $(56.3 \%)$ have their own desire to study at the Faculty of Nursing. More than half borrow one book at the library once a week $(63.6 \%)$. More than half of the respondents earn a GPA of at 3:00 to $3: 25$ (57\%). Table 2 illustrates the average characteristics of the respondents in the search for the journal are 8:06 hours in a week.

Table 2. Characteristics of Respondents by Interval looking Journal

\begin{tabular}{lcc}
\hline \multicolumn{1}{c}{ Variabel } & Mean & SD \\
\hline $\begin{array}{l}\text { Interval looking at the journal } \\
\text { website (hours) }\end{array}$ & 8.06 & 8.37 \\
\hline
\end{tabular}

Table 3 illustrates the ability of Critical Thinking and Decision Making Skills on respondents. More than half of respondents (66.2\%) have the ability to think critically above the group average $(\mathrm{M}=186.19, \mathrm{SD}=$ 33.92). More than half of the respondents have the skills to make decisions above the group average $(\mathrm{M}=94.92, \mathrm{SD}=9: 52)$. 
Table 3. Critical Thinking and Decision Making Skills Semester 7 Students Faculty of Nursing, University of Padjadjaran

\begin{tabular}{lcc}
\hline \multicolumn{1}{c}{ Variable } & Distribution & Persentage \\
\hline $\begin{array}{l}\text { Critical Thinking skills } \\
(\mathrm{M}=186.19, \mathrm{SD}=33.92)\end{array}$ & & \\
- below mean & 51 & 33.8 \\
- $\quad$ above mean & 100 & 66.2 \\
\hline Decision Making skill & & \\
$(\mathrm{M}=94.92, \mathrm{SD}=9.52)$ & & \\
- below mean & 70 & 44.9 \\
- above mean & 86 & 55.1 \\
\hline
\end{tabular}

Tables 4 and 5 describe the crosstab critical thinking skills and the skills to make decisions based on GPA and background majors SMA. Table 4 illustrates, as many as 57 respondents with a GPA of 3:01 to $3: 25$ has the ability to think critically above the group average. A total of 50 respondents with the same GPA groups also have the skills to make decisions above the group average. Table 5 illustrates, a small portion of respondents background science majors have the critical thinking skills and decision making skills above the group average.

Table 4. Crosstab Critical Thinking and Decision Making Skills Based on GPA

\begin{tabular}{llllll}
\hline Variabel & \multicolumn{5}{c}{ IPK } \\
\cline { 2 - 6 } & $\mathbf{2 . 5 - 2 . 7 5}$ & $\mathbf{2 . 7 6 - 3 . 0 0}$ & $\mathbf{3 . 0 1 - 3 . 2 5}$ & $\mathbf{3 . 2 6 - 3 . 5}$ & $\mathbf{3 . 5 1 - 3 . 7 5}$ \\
\hline Critical Thinking skills \\
$\begin{array}{l}\text { (M=186.19, SD=33.92) } \\
\text { - below mean }\end{array}$ & 8 & 29 & 11 & 0 \\
- above mean & 0 & 13 & 57 & 28 & 2 \\
\hline Problem solving skill & & & & \\
(M=94.92, SD=9.52) & & & & \\
- below mean 0 & 10 & 36 & 20 & 2 \\
- above mean 3 & 10 & 50 & 9 & 0 \\
\hline
\end{tabular}

Table 5. Crosstab Critical Thinking and Decision Making Skills with Background High School Programs

\begin{tabular}{|c|c|c|c|c|}
\hline \multirow[t]{2}{*}{ Variabel } & \multicolumn{4}{|c|}{ High School Background } \\
\hline & Science & Social & Techni & thers \\
\hline \multicolumn{5}{|c|}{$\begin{array}{l}\text { Critical Thinking skills } \\
(\mathrm{M}=186.19, \mathrm{SD}=33.92)\end{array}$} \\
\hline - below mean & 46 & 2 & 2 & 1 \\
\hline - above mean & 97 & 0 & 0 & 3 \\
\hline \multicolumn{5}{|c|}{$\begin{array}{l}\text { Problem solving skill } \\
(\mathrm{M}=94.92, \mathrm{SD}=9.52)\end{array}$} \\
\hline - below mean & 66 & 0 & 1 & 1 \\
\hline - above mean & 76 & 2 & 1 & 3 \\
\hline
\end{tabular}

\section{DISSCUSSION}

The results showed more than half of respondents $(66.2 \%)$ have the ability to think critically above the group average $(\mathrm{M}=$ 186.19, SD = 33.92). Research conducted by Evancho (2000) using the California Critical Thinking Disposition Inventory Facione \& Facione research (1992). The questionnaire was consists of six domainsare the truth (truth-seeking), the insight that open, analytical, systematic, critical thinking skills, inquisivity, judgement mature. The results of the Evancho (2000), critical thinking skills in undergraduate students did not change significantly after the given program. Research results Evancho (2000), there is no relationship GPA with critical thinking skills. Based on Watson \& Glaser (1964) in Shin (1998), critical thinking as composite of attitudes, knowledge and skills. Shin (1998) described critical thinking is a essential component of precise communication, problem solving ability, theoretical and conceptual understandingog nursing concern. Student nurses are expected to be able to think critically in order to give nursing care.

The aim in the implementation of nursing education is to print professional nurse. One of the competencies that must be owned by a student nurse is the ability to think critically. Learning how to think critically is regarded as a amjor goal of nursing education. Results of this research is still below the average of the results of research Evancho (2000). Factors that affect the ability of critical thinking in students was curriculum of nursing education. Nursing education curriculum used in the Faculty of Nursing mostly using Problem BasedLearning. According Facione \& Facione (1996), selecting the cases and provide an overview as well as open questions can hone critical thinking skills of students. The same thing was also stated by Simpson and Courtney in the literature review that PBL has been good at producing high critical thinking skills and problem-solving skills. Factors that 
may affect the ability of other critical thinking was an accepted practice by many students.

More than half of the respondents have the skills to make decisions above the group average $(M=94.92, S D=9: 52)$. This is very much different from the average of the research group Baumbarger-Henry (1998) (M $=148.4)$. Questionnaires skills to make decisions using the questionnaire used in the study Baumbarger-Henry (1998) which is used on students who have been exposed by the nursing area either in the clinic or community. The results obtained in this study related to various factors. Respondents still in the seventh semester so rudimentary getting all the subjects in the study program S-1 Nursing. Decision-making is based on the experience gained, complex cases and practices undertaken (Baumbarger-Henry, 1998). According to Hughes and Young in Baumbarger-Henry (1998), nurses must be proficient in taking decisions in accordance with the facts, not based on the value and perception.

\section{SUMMARY}

More than half of respondents $(66.2 \%)$ have the ability to think critically above the group average $(\mathrm{M}=186.19, \mathrm{SD}=33.92)$. More than half of the respondents have the skills to make decisions above the group average ( $\mathrm{M}=$ 94.92, $\mathrm{SD}=9: 52)$. A small portion of respondents with a GPA of 3:01 to $3: 25$ to have critical thinking skills and decision making skills above the group average. A small portion of respondents background science majors have the critical thinking skills and decision making skills above the group average.

\section{SUGGESTION}

The ability of critical thinking and decision making skills should be incorporated into the academic curriculum. Research to do next is testing methods of learning in addition to Problem-Based Learning by using questionnaires used in this study.

\section{REFFRENCES}

Arjanggi R, Suprihatin T. 2010. Metode Pembelajaran Tutor Teman Sebaya Meningkatkan Hasil Belajar Berdasar Regulasi-Diri. Makara Sosio Humaniora.

Bower, Susan. (2004). The Effect of PBL on Nursing Student Clinical Decision Making and Learning Satisfaction. Dissertation of University of Dakota.

Evancho S. (2000). Critical Thinking Skill Disposition of Undergraduate Baccalaraute Nursing Student. Dissertation of Southern Connecticut University.

Facione \& Facione. 2000. What is Critical Thinking. Available in insight assessment.com.

Isnaeni, ely (2011) Penerapan Seven Jump Method Dalam Meningkatkan Minat Dan Kompetensi Mata Kuliah Kebutuhan Dasar Manusia (KDM) Ii Mahasiswa D3 Keperawatan Stikes AnNur Purwodadi. Phd thesis, Universitas Sebelas Maret.

Rahmalia, Siti; Erwin . 2014. Peningkatan Kompetensi Mahasiswa Pada Mata Ajar Keperawatan Gawat Darurat Melalui Penerapan Metode Seven Jump URI:

http://repository.unri.ac.id/xmlui/handl e/123456789/6288.

Shin KR. 1998. Critical Thinking Ability and Clinical Decision Making skills among snior nursing student in Associate and Baccalarate programs in Korea. Journal of Advanced Nursing. Volume 27 Issue 2 February.

Simpson E, Courtney M. Critical Thinking in Nursing Education : a literature review 